\title{
Simple Hide-and-seek at its Core: Play Features and the Game of Geocaching
}

\author{
Mare Kalda
}

\author{
Department of Folkloristics, Estonian Literary Musem; \\ Center of Excellence in Estonian Studies \\ kalda@folklore.ee
}

\begin{abstract}
Since 2000, people all over the world have been engaged in geocaching, a game of hiding and seeking geocaches, in the course of which "treasure boxes" are hidden and sought using navigational techniques and information technology. Caches are placed in concealed locations in physical space, and the information that the participants jointly manage and renew is uploaded to the Internet, where communication takes place. The aim of this research is to juxtapose geocaching with the play features highlighted in classical ludology as well as present other possibilities of categorisation which have been applied in previous studies of this recreational activity. While discussing the playfulness of geocaching, the author points out the peculiarities of ludic traits of the hobby in order to diversify folkloristic knowledge with developments in the game genre on the one hand, and modification of the idea of treasure hunt on the other hand under the cultural conditions of the information era. The article focuses, above all, on geocaching in Estonia, yet also offers insights into the game on an international level.
\end{abstract}

Keywords: geocaching, pervasive game, locative game, enactment genres, play

So, what do we do when games become our most important cultural genre?

- Espen Aarseth

The invention of geocaching is among the many events with worldwide impact that occurred on the eve of the 21st century, so to say, or in the year 2000. After the first "treasure box" of the game was hidden in Portland, Oregon, and the fact was announced to news group for GPS users in May 2000, the game quickly gained popularity. Conventions for the game developed: someone hides a container with some objects, determines the geographical coordinates of the cache and makes a post about a new treasure on the website geocaching.com. Using the information posted, anybody can attempt 
to find a cache and report findings on the previously mentioned website, jointly used by geocachers. ${ }^{1}$

This is how an individual act by one person (Dave Ulmer, an IT consultant from Portland, Oregon) developed into a hobby that brings together a great number of people. When geocaching.com was launched, the game included - according to an overview by Ken Jennings - 75 caches (until then, caches were simply listed on a website which was unable to handle user traffic as early as in the autumn of the first year of its use). From 300 caches in early 2001 , the website quickly came to include 10,000 caches by the end of 2002, and in March 2010, the game included one million active caches (Jennings 2011: 237-239). By 15 July 2015, 2,670,796 active caches had been listed internationally. In the beginning of May, 2017 more than 2,800,000 geocaches are waiting to be found (see the first page of geocaching.com). The 21st-century treasure hunt represents a game of hide-and-seek in a novel form: navigation and positioning devices are used and a specially designed online environment is needed to view continuously updated information about the game and to share it with others. The activity springs from the need to play games and for stimulation, both characteristic of humans, and seems to correspond to the interests of time-conscious people, who playfully test IT-solutions outside their work tasks. The elementary idea of hide-and-seek, one of the hidden-object games in the traditional classification of games (Georges 1972: 177, 184; Kalmre 2005: 172), is renewed and adapted to the conditions of the information society. The hobby is highly democratic in essence everyone who is interested can join in.

As the following is largely based on how geocaching evolved in Estonia, numerical data on its local development is also presented. The first local cache was hidden on February 10, 2001 by computer software professional Enn Veenpere, who created the original webpage for managing the regional version of the worldwide game he suggested be adapted here (Veenpere 2002; see also HE-aare 2001). His initiative proved successful, and geopeitus also began to have players in Estonia. Submitting new caches, constantly reporting the findings of already existing treasure boxes, and discussing the game in forums, the local geocaching community contributes actively to the development of both online and offline parts of the 
geopeitus. In parallel, most Estonian hobbyists regularly log their playing actions on geocaching.com. The caches hidden in Estonia are also listed on the common international webpage. This means that the Estonian geopeitus constitutes a part of the worldwide game and geopeitjad ('geocachers'), along with the other 7 million people (according to the front page of geocaching.com), belong to the big community of participants.

An overview of the current state of geocaching in Estonia is given at http://www.geopeitus.ee/statistika, which provides statistical data. Diagrams show the dynamics of the game: data about logs, messages and new caches indicate how, until 2008, the game gradually escalated in popularity: a clearly noticeable rise in participation can be seen in the years 2009-2010. As of May 2017, there were 2,988 caches (831 of them archived, i.e., no longer extant). The number of more active participants amounted to nearly three hundred people. The geopeitus database comprises a plethora of photos $(50,357$ in May 2016). Over 25,726 posts have been made in different forums.

\section{Exploration of Geocaching from Multiple Perspectives}

Before the geocaching era, my relationship to the research object was mostly textual. I have conducted folkloristic research comparing treasure legends and personal experience stories. I have tried to trace the origin of traditional motives as well as reconstruct contexts around the old, supposedly "dead" archival pieces of folklore. I have used summertime fieldwork to interview people who knew traditional treasure lore, and hoped to grasp stories' meaning for narrators. Folkloristic routine did not include treasure hunting, unless the researched stories themselves were regarded as symbolic hidden treasures, while their collection and study equated with a treasure hunt. In April 2002, when my geocaching team found our first cache (the Aastapäeva cache), I became a geocacher. The hobby turned out to be preoccupying and gripping, as it enabled me to try something different.

At the same time, I perceived that this playful practice was worth investigating from the folklorist's viewpoint. There are already a few research examples of the folkloristic approach: an overview about how the elements of traditional folklore (especially local legends) 
are integrated into games dates back to 2007 (see Kalda 2007). The game under discussion has also been addressed by Lynne McNeill, who acknowledges the folklore genre system avoids categorising geocaching as a game. She relates playful activity to the analytical idea of serial collaboration and portable places, and concludes: "All instances of serial collaboration entail both an object and a process, leaving the tradition generically stuck between material culture and custom (not to mention the emic category of 'game', which many participants use in their descriptions)" (McNeill 2007: 288). Going into the details of the ludic features of the activity was actually not her intention.

Since the very beginning, geocaching has been a ubiquitous phenomenon which, during the last ten years, has been analysed from different angles by game researchers with varied backgrounds as well as by cultural geographers, digital communication experts and web designers. The things experienced bodily in the real world and the procedures carried out in a virtual environment at the same time do belong to actual geocaching, alternate and intertwine: in contemporary game categorisation, geocaching is a pervasive game (Montola \& Stenros \& Waern 2009: 31-33). Characteristically to such games, we can follow how city culture, mobile technology and network communication is interconnected with information from various sources and fields of activities to produce new play experiences (ibid.: 7).

Jason Farman characterises constant interplay between online and offline space, formulating how the "player's embodiment is developed simultaneously between the zones of perception and invisibility, between resistance and hegemony, between technology and the body" (2009: 3). Pirita Ihamäki also tends to emphasise the mixed-reality properties of geocaching: here the real and virtual environment merge; by means of information and communication technology, traditional game areas are transcended and as a result, a new expanded environment emerges in which the user's real surroundings become an essential component of the entire game (Ihamäki 2012: 141). Mixed reality is created by interactive maps on smartphones, the ability to visualise a path on the GPS screen, itinerary video from the car camera and sometimes electronic devices put into a caches. In a sense, the pervasive game approach and 
the mixed reality perspective seem to describe one and the same phenomenon. Kenton O'Hara (2008: 1179-1182) makes several good points highlighting the motivations of people involved in the game, like giving a walk a sense of purpose, discovering new places, locating more caches, experiencing friendly competition and finding opportunities for social interaction.

In a paper focusing on the new playing research methodology, Espen Aarseth holds that in order to understand a game, "all we have to do is to play it well" (Aarseth 2003: 5, 7). Jaakko Stenros, Annika Waern and Markus Montola claim the same, emphasising the role of participatory observation that co-playing enables (Stenros \& Waern \& Montola 2012: 345-346). Indeed, participant observation is one type of research method typically used in studying virtual worlds. To the extent a researcher observes the activity of a community to which he/she belongs, it can be said that the study is conducted from the auto-ethnographic perspective. According to Leon Anderson, this means membership of the researcher in the research group and his/her personal experience is made visible in published writings and the investigated phenomenon is viewed in a wider social context (Anderson 2006: 373). To a certain extent, participation in the activity studied includes associating with the community studied, informing them of the research activity and presenting its results. While reflecting on geocaching, I have tried to adhere to those methodological principles. Because the information platform of geocaching is created through shared contribution and in online discussions and co-players debate over the many problems occurring over the course of the game, the study takes on features characteristic of shared authorship.

The truth is that the webpage for Estonian geocachers contains almost all game-related information and communication gathered over the years of playing as if by itself. Considering data acquisition methodology and looking from the point of view of folkloristic source criticism, we encounter an interesting situation: pieces of information are collected without collecting. There is no burning need for an additional search for "variants" of the phenomenon under study, because the whole action is constantly represented, displayed in a user-friendly manner. Arvo Krikmann, the internethumour researcher, has noticed almost the same situation regarding 
his study materials: users upload jokes to internet sites where these are collected and preserved at the same time, combining them into a virtual publication. He called this kind of data "natural archives" (Krikmann 2005: 75-76).

Cache logs posted online on geocaching.com and geopeitus.ee (elsewhere as well) after seeking, as well as topical forum discussions, can be regarded as valuable sources for cultural studies (folkloristics included). The same has been noted by Tom Boellstorff, who investigates the virtual world of Second Life. According to him, the activities and words of residents there are fully legitimate data about their common environment (Boellstorff 2008: 60-86). Trevor Blank also validates every kind of user-generated content on the vernacular web, arguing more generally that the authenticity of the data collected online is as valid as data collected in person (Blank 2009: 19). Internet ethnography proves to be a relevant method for describing the content of geopeitus.ee and geocaching.com as sources for geocaching studies in order to comprehend the activity and the knowledge produced therein. For example, the geopeitus. ee webpage provides answers to questions about what (Estonian) geocachers actually do while geocaching, what they experience, how the geocaching activities are prepared, what may cause positive or negative reaction, how intensively someone pursues his/her hobby, what kind of strategies are employed, which geocaches are preferred, how the new caches are accommodated to their surroundings, what the conventions are for writing log entries, how geocachers communicate, etc. Thus, virtual ethnography used in combination with opportunities for participative inquiry will be functional.

In characterising the modern socio-cultural situation, it is claimed that a casual revolution is taking place in the world (Juul 2009), games become the most important cultural genre (Aarseth 2003) and we perceive the ludification of contemporary culture (Frissen \& de Mul \& Raessens 2013). This has become possible because the nature of work and, as a result, the distinction between work and leisure have changed. Play is in no way restricted to childhood any more.

Under these conditions culturologists and ludologists have posed research questions like Espen Aarseth explicitly did: "How do we investigate, and why do we want to make games and gameplay our object of study?" (Aarseth 2003: 1). It has become customary 
in interpretation to re-examine the concept of play and rediscuss the features of these activities, referring to the works by Johan Huizinga, Roger Caillois, Gregory Bateson, and Erving Goffman. A folklorist as a representative of a specific area in cultural studies has to continue in the same vein, approaching play and games with analytical tools characteristic to his/her discipline. Therefore, the present study aims to review the position of games in the folkloric genre system using geocaching as an example of novel phenomena. Although different forms of folklore have been blurred since times of old, really new or seemingly new appearances will re-blur the genre system again.

Game researchers rhetorically and/or essentially differentiate between traditional games and videogames, or assign special significance to high-tech gadgets and gamers' online performance. One of my questions inspired by geocaching events is whether the technology changes the play on an essential level. ${ }^{2}$ Indeed, geocaching cannot be geocaching without identifying one's location on the earth, or using online cache listings and accessing fellow geocachers' logs. However, can we take it just as a (not so simple) hide-and-seek game for things which is elaborated and modified, and played partly synchronously and partly non-synchronously by a very, very large group of participants? And does the "geocaching man" differ from the "playing man", homo ludens? Or is geocaching perhaps more closely associated with orienteering sports - outdoor recreation which combines navigation with maps to find various points in the landscape and provides competition? Yet orienteering is not about treasure hunting - anything but play in real life. At the same time, the topic of hidden treasure has implicitly belonged to traditional folklore, where it mixes facts, somebody's personal experiences and rumours on the one hand, and fantasy motifs and episodes of migratory legends on the other hand.

As of geocaching, a folklorist faces the activity that brings together words and deeds previously framed otherwise in out-of-game reality: the idea of treasure hunting, the category of play as special practice, versatile information-technology use, community-shaping and a sense of belonging into a hobby group as well as shared representation of the practice on the participative web and both online and offline interaction of participants, if not to talk about the places, 
items and situations pulled into the game constantly. Inasmuch as we deal with the tradition-creating phenomenon and the group of people involved, the ongoing process can be interpreted as a kind of expressive behaviour approachable from the folkloristic perspective. This means careful gathering and inspection of data related to the investigable content, i.e. answering several what, how and for whom questions. So much attention to the research procedure is given because I have been criticised in choosing an unclear addressee for my interpretation: it's not about folklore, it's about leisure studies or research of information society. However, as was already said: inasmuch as a group of people (i.e. folk) is involved who repeatedly perform the specially focused form of action - in the present case, playing (geocaching) - a folklorist might join and highlight the process through a folklore lens.

Accordingly, at first I will observe, in brief, the categorisation of geocaching. Thereafter, based on works of classical ludology, the events taking place and components employed in geocaching are related to the features of play. Linking general characterisation with the example of the particular locative game would bring to the fore changes happening in performative genres.

\section{A Game, Hobby, Entertainment, and/or Recreation?}

I would not hesitate to classify geocaching (geopeitus) as play. However, the ubiquity of the activity seems to influence the way it is realised and framed by different people: thinking and talking about the thing, whether it is called a pastime, interpreted as an example of another hobby or characterised as a kind of practice. Again, at first sight, high-tech hide-and-seek really does not demonstrate a connection to the folklore-creating processes or folklore genres either. If the individual framework of interpretation will support considering the occurrence of play, it is easy to see the relation. At the same time, play as such can certainly be, and in fact is, a mode of entertainment and a hobby categorisable as a specific practice. It appears that we have a handful of partly overlapping, partly differing concepts referred to above which are relevant enough to describe play in general and geocaching in particular. 
What a folklorist does at first is to find out where the phenomenon under study is situated in a previously functioning cultural genre system and whether the new or seemingly new process will change the situation. Accordingly, geocaching is categorised as play, the ludic features of which will deserve further consideration.

As early as in 1977, in connection with growing interest toward performative forms in folkloristics, Roger Abrahams elaborated the theory of enactment genres that considers performances, games, rituals, festivities and parties. According to him, "all enactments are drawn, to some degree, from everyday life and yet set apart from it" (1977: 94). His reasoning awakens attention and can be helpful for geocaching research because he posed the question about the relationship between real experiences and their counterparts in one or another type of enactment (ibid.: 88) - the issue has risen again in relation to the present-day ludification of culture. The researchers of locative and/or mixed-reality games as well as anthropologists observing life in digital worlds focus on how players (and/or virtual world residents) switch between play (a sort of enactment in Abrahams's sense) and non-play, between online versus offline actions, and at the same time pay attention to the character of experiences gained. The ubiquitous computing enables variable involvement in different kinds of enactment to a great extent, thus - as Michiel de Lange, the researcher of new media states - changing "the temporal segmentation between normalcy and being at play" (2009: 13-14). It appears as if physical world experiences were a part of game world experiences. At the same time, the experiences gained during "more highly focussed, framed and stylized" acts (see Abrahams 1977: 85 ) performed online and offline take effect in the physical world. The special sensation of being engaged arises not only during the actual seeking for geocaches or communicating online with fellow geocachers, as is expected, but at arbitrary moments in the course of daily events and under conditions not explicitly connected to the hobby. The ongoing nature of locative play makes Michiel de Lange ask whether Bliin - his relatively geocaching-like target of research - can be considered a game at all (see Lange 2009: 59).

The topic of categorisation is sometimes also discussed in the inner circle of hobbyists via forums. For example, in May 2005, there was a quite heated discussion on this issue on an international forum (see: 
Is Geocaching A ... sport). Some qualified the business as a sport, while others considered it to be a game and type of recreation. Various characteristics were posted to prove the validity of either one or the other option. Geocacher Glenn shared his Google search result, which elicited about sixty definitions or definition-like descriptions about what geocaching is or is not. The arguments regarding competition versus co-operation, compulsive involvement versus now and then geocaching, difficult-to-find versus easy-to-find caches, desire to get a high score versus to be cheerful whatever you gain were brought out by posters. The discussion was held despite the fact that in 2002, the acronym RASH (recreational activity/sport/hobby) (see RASH) was already discussed in a similar debate, in which some posters responded positively, while the rest heatedly opposed the acronym. Many contributors valuated the game just because of the fun it created. Interestingly, a couple of years ago the activity was explicitly defined as a game: "Geocaching is a real-world, outdoor treasure hunting game using GPS-enabled devices." At the present time, according to geocaching.com, the characterisation of the activity looks somewhat different: "Geocaching is an outdoor adventure where players use free mobile app or a GPS devise to find cleverly hidden containers around the world."

Researchers with different backgrounds employ the same categories in order to describe the occurrence, using the notions "game" and "hobby", as well as the more general "activity". Lasse GramHansen's approach emphasises the playfulness of geocaching most intentionally, demonstrating the persuasive perspective of the hobby for those who take pleasure in such a symbiosis of discovery and technology (Gram-Hansen 2009). Francis Hawley, who investigates geocaching as a sport, lists all mentioned aspects at a time: "Geocaching is a sport, a hobby, a pastime and a recreational activity, which requires, in order to find 'caches', data obtained by a computer, as well as maps and a GPS-receiver" and which in a few cases can even involve "features of planned deception and criminallike behaviour" (Hawley 2010: 225, 227; 233-234). Heather Skinner, Gareth White and David Sarpong, experts of business management and marketing, in the marketing organisation's annual meeting report focusing mainly on the use of mobile technology in tourism, classify geocaching as a social practice. On the basis of the featured articles on the practice theory of the late 20 th and early 21 st cen- 
turies, they discuss geocaching as a complex form of social activity, within which people, through the support of agreed upon rules, make joint efforts for common action; shape internal goods, which cannot be obtained in any other way than by participating in this practice (for example, energy spent on both hiding and seeking as well as experienced emotions); possess specific skills and expertise; and deal with the history of their undertaking (Sarpong \& White \& Skinner 2012: 2-3). Being, on the one hand, a social practice, they regard geocaching as a high-tech version of a treasure hunt, a sport and a pastime (ibid.: 1).

It appears that geocaching moves conceptually in the semantic field of a number of practices. One aspect is the use of appropriate notions in accordance with descriptive language chosen for cultural analysis of a new, ongoing phenomenon. At the same time, words employed for categorisation should reveal the essence of the activity under discussion. The category that is decided on to classify geocaching creates an effect on understanding what is actually going on. Linking the occurrence with several sorts of human deeds, for example, identifying geocaching as a high-tech game and treasure hunt, recreation and leisure time, sport and hiking, time waster and addiction, etc. as was referred to, we seemingly pull together meanings of different realms of actuality to reach intelligibility. Thus, for the sake of intelligibility, the novel form of behaviour will be adapted to existing categories which, enriched by new content, also begin to change.

\section{Where is the Playground of Geocaching?}

The next part of the paper is dedicated to the juxtaposition of play features defined by Johan Huizinga with those occurring in geocaching. Particular aspects, characteristics and routines can be detected in geocaching which distinguish it from other games and make the hobby special. The factors to be highlighted are boundaries between play and non-play as well as between play and ordinary life, including geocaching mood and mystery, the players' subordinatedness to the rules and, simultaneously, manifestation of free will. 


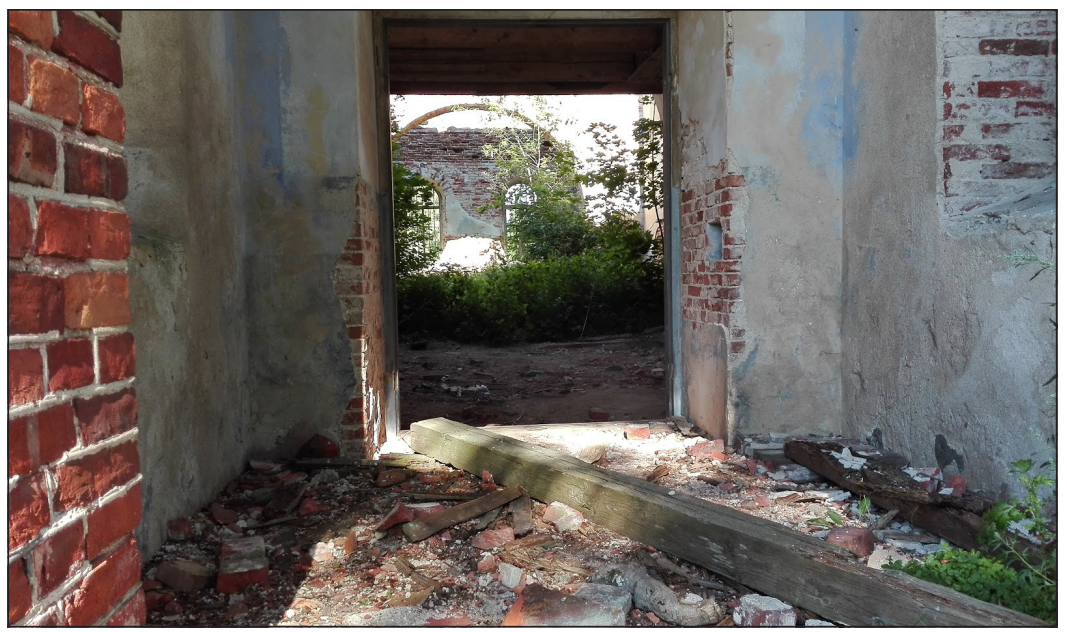

Figure 1. The hobby leads us to places we might never visit otherwise. In location of the "Batjuška 4". Photo by Mare Kalda (2016).

Among the formal features of the activity, Johan Huizinga (2003 [1938]: 18-19) accentuated the spatial limits of play also common to ritual:

All play moves and has its being within a play-ground marked off beforehand either materially or ideally, deliberately or as a matter of course. Just as there is no formal difference between play and ritual, so the consecrated spot cannot be formally distinguished from the play-ground. The arena, the card-table, the magic circle, the temple, the stage, the screen, the tennis court, the court of justice, etc., are all in form and function play-grounds, i.e., forbidden spots, isolated, hedged round, hallowed, within which special rules obtain. All are temporary worlds within the ordinary world, dedicated to the performance of an act apart. ${ }^{4}$

But where is the playground geocaching is carried out? Do we, by hiding and seeking containers outdoors and reporting online via 
cache listings create a temporary world within the ordinary world to participate in the shared hobby? For example, Minhao Zeng from the University of Alberta, discussing the high degree of connectedness of geocaching to the material world in comparison with other locative media applications, regards websites as merely a repertoire of treasure information and a forum for exchanging caching experiences, while real playgrounds for geocachers are offline, in the real world (2011: 115). In a sense, the online environment of geocaching. com also functions as a place that must be visited for the sake of the game, although this site (as well as geopeitus.ee and other similar sites) certainly does not serve as an online world in the same way as, for example, the Sims or Second Life do. Nevertheless, it can be perceived just about as well as the well-appointed virtual home by the people who participate in the game. It holds true especially for the Estonian website, which in comparison with the information platform common to the whole international geocaching community, provides a place for more intimate communication and longer stories related to the game. It is both customary to log on to share experiences after a caching tour as well as necessary to log on before caching to gather relevant information for the next search.

While geocaching, increasingly more locations on physical land become seemingly recolonised gradually, which results in changing an otherwise irrelevant space into related places of interest for the playing community. The question is whether to interpret the locations for hiding caches as signs of distinguishable play space or just as concealed places in the ordinary world, not necessarily a special playing field marked off beforehand for game-related actions. At any rate, we can see an example of the playful use of real places, somewhat different from how traditional games are played, that the game pieces are meant to stay in one place in geocaching. While in traditional games game pieces are usually gathered up or left aside after the game is over, geocaching continues seemingly without cease thanks to always available containers to be searched for. Thus, the hobby seemingly redefines the otherwise non-game reality, which somehow recalls a digital map, enriched by the new data layer(s).

For pursuing their hobby, geocachers are eager to take advantage of mobile computing that enables - guided by the GPS signal on 


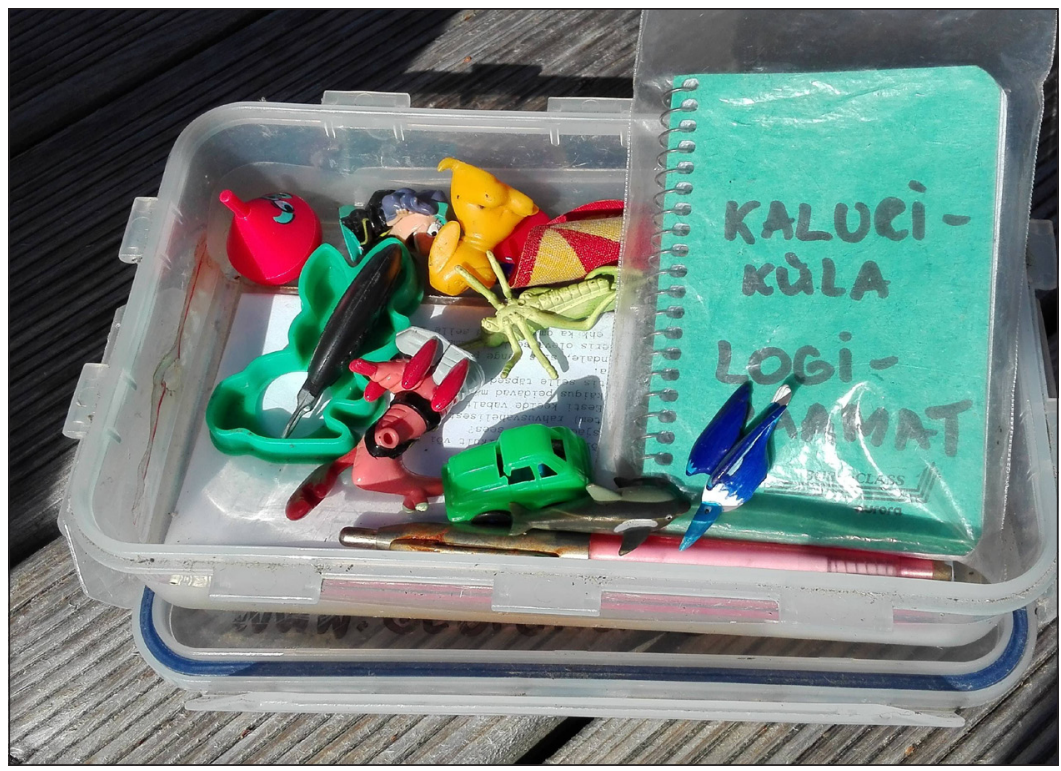

Figure 2. An example of a cache hidden in Läänemaa county, Estonia. Photo by Mare Kalda (2016).

the screen of smartphone - the location of a particular cache to be found, and during the process of seeking, retrieve additional data online. Thus, we can process geocaching information as well as be connected with fellow hobbyists whenever and wherever we want: either immediately during the search or in between other tasks not connected to geocaching at all.

Under these conditions the whole world becomes a playground for geocaching - an idea already articulated by researchers and players themselves. According to investigators of contemporary gaming culture Markus Montola, Jaakko Stenros and Annika Waern (2009), the spatial expansion into the real world characterises all pervasive games, geocaching included. The others debate the formation of hybrid space, which comes into being by blending the physical and the digital. Thus, the focus lies not so much in defining the 
geocaching playground but in the novel spatial layer generated by the games merging physical and digital components. Michiel de Lange brilliantly makes the situation intelligible: hybridity is not a mix of digital and physical nor virtual and real but "a specific composite in which the distinct elements are still visible and their differences are important and meaningful to make it into a playlike activity" (de Lange 2009: 63). His interpretation of Bliin also holds true with regard to geocaching: "enjoyable exploring of our surroundings while we are on the move, feeling of perceiving at least two different realms at the same time, fun derived from doing something out of the ordinary in previously impossible way" (op. cit.: 64). He argues, however, that boundaries still exist when play goes on in hybrid space in spite of the obvious expansion of spatial, temporal and social limits occurring in locative games.

\section{Ordinary or Extraordinary Action?}

As was already said, beyond the playground problem is one about the differentiation between play and non-play. According to classical ludology, "a game is not ordinary or real life but rather stepping out of it into the sphere of temporary activity, which has its own acting direction" (Huizinga 2003: 17). In the 1970s, Roger Abrahams, describing the theory of enactment, characterised all performative genres, games included, as being unreal yet more real at the same time - everyday motifs and scenes are brought into a new perspective that results in seeming detachment from ordinarity (Abrahams 1977: 80-81, 84). In contrast, Richard Schechner, the performance studies theorist, maintains the idea of continuity instead of separateness, and suggests thinking of play not as the interruption of ordinary life but as "the underlying, always there continuum of experience" (1993: 42).

Inasmuch as geocaching is a game, the universal qualities of the game matter for its explanation or, at least, deserve closer investigation. In what sense is the hobby set apart from everyday life is therefore the question that makes sense to ask as well as whether the experience of involvement into geocaching bears resemblance to similar experience gained from being active, for example, in any virtual world. Virtuality in the form of fantasies and dreams, games, fiction, art and rituals has actually always been part of the human 
experience. Digital virtuality just creates the feeling of more active participation in it, or using the words said by gamers cited in the paper by Jaron Harambam, Stef Aupers and Dick Houtman (2011: 306): within virtual game worlds they can do at least as much as in real life and often even more.

Huizinga's idea of stepping out into a temporary activity while playing doesn't actually mean rigid detachment from reality. At the same time, acting in digital virtuality has increasingly become part of our mundane reality. For example, looking from the viewpoint of a hard-core gamer, playing video game is part of ordinary life, not a stylised behaviour in exultation. Even if the impression of being somewhere else occurs, the locative play seemingly directs the players back or closer toward the mundane reality. Furthermore, different games are stepping out into the special activity somewhat differently - role playing demands more focused behaviour from the people engaged in it. Pervasive games tend to blur the otherwise perceivable border between real life and play; the game invades everyday life, and everyday life invades the game, as Jaakko Stenros, Annika Waern and Markus Montola (2012: 341) affirm.

We can follow yet another interesting situation: geocachers will view the world through the game prism, and the experiences gained while geocaching will become a significant part of their life experience. Being engaged in the game due to its bodiliness and performativity potentially also influences the being in the ordinary world. Interestingly, the contacts and clashes between the game situations and the "outside" world are constantly experienced by the hobbyists as well as discussed and represented afterwards using all communicative means of geocaching, including face-to-face talk in different contexts, forum conversations and log entries in the cache listings.

The example below illustrates specifically how the hobby intersects with everyday affairs. A seeker of the Vandi cache tells about the search in July 2009:

I put a pot with potatoes on the cooker and switched on the computer. What? someone has hidden a cache in Tartu? In order to confirm the legend that if anyone places a cache in Tartu, the first-to-find would be Aints or Lassie, I set out. When I arrived, I found a geomuggle there who thought he 
was fishing. I thought differently and soon he was forced to leave for better fishing places. There was all kind of rubbish on the bridge from yesterday's bridge-opening event. And, one by one, citizens will come here to see and take pictures of the new bridge for at least a couple of months. I got back home, and the potatoes were ready. It was a nice morning FTF. (see Vandi 2009)

The question of manipulation with objects in geocaching can have specific interpretative value because of the symbolic or reversed reference to the actual conditions of hiding wealth. In the former context the hiding locations are created for playing purposes; in the latter case it is done under particular circumstances - in fear of war (political) or as a deposit (economic motif). In this regard, contrary to the idea of blurring the boundary between play and non-play, we face the obvious difference between the categories mentioned above. The similarity of two hiding procedures lays in the fact that in both cases there are artefacts deliberately placed into concealment. Real treasures are supposed to have real material value, while geocaches may seem worthless as well as senseless for the out-of-game reality. At the same time, the caches are still concrete items which at first sight might be regarded as objects of desire passionately searched for. Though there are trackable items specially rated in the game and people who collect the trinkets they get while pursuing their hobby, the thing itself is not nearly as valued as is finding it; rather we can see a strange ambiguity in this regard. Usually the seekers don't trade at all; they just make an entry in the logbook by adding the coded message TNLN (to be read as "Took Nothing, Left Nothing"). On one hand, participants don't give special status to hidden objects, which preserves their usuality. On the other hand, hide-and-seek is certainly another kind of action compared with searching for something without purpose for play. Play can be a special action using ordinary things, or vice versa: ordinary action with extraordinary objects.

As early as in the 1960s semiotician Yuri Lotman presented the highly relevant train of thought concerning the double-faced essence of play: "Play is the simultaneous realization of practical and conventional behaviour... The ability to play means mastering such twofold behaviour" (Lotman 2011 [1967]: 254). Recently, in 


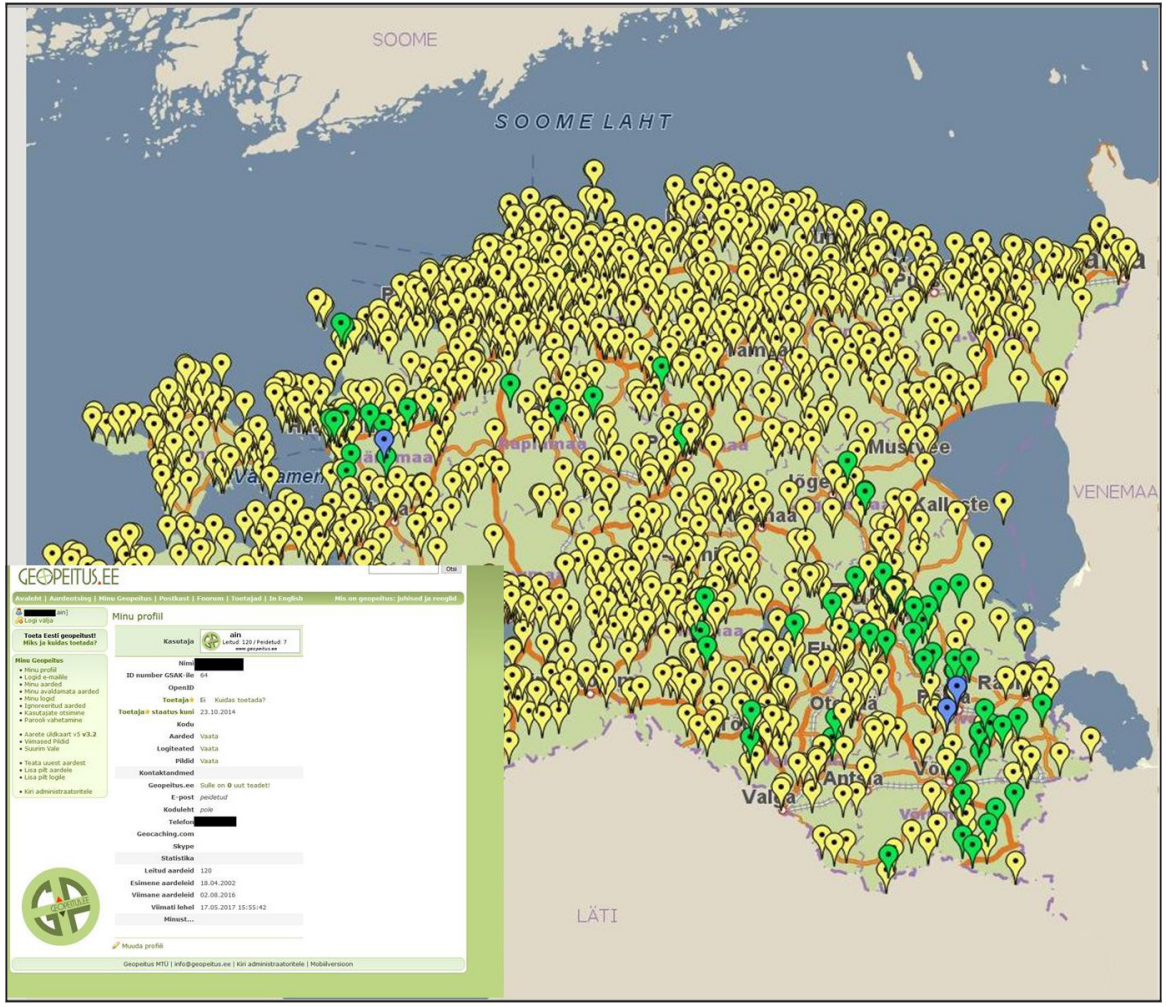

Figure 3. A personal "treasure map" generated by the program, and the profile of a geocacher. The profile can be seen by fellow hobbyists while logged in. A screenshot of geopeitus.ee on May 2, 2017.

2013 Valerie Frissen et al. reached an almost similar conclusion, discussing how a player simultaneously moves in the ordinary world and in the play world while being aware of the simultaneousness of both worlds (Frissen \& de Mul \& Raessens 2013: 81). Thus, the play as the activity in spite of, or rather due to, its own acting direction should fit well into non-play, depending of course on the nature of the particular game currently played. It appears that locative games like geocaching are played greatly in a non-play-like way, slightly modifying otherwise practical behaviour. In this regard, 
many usual, in other contexts non-play activities are carried out while geocaching: we have to explore several places, to drive and hike, to gather (and sometimes process) various information from all conceivable sources online and offline, to count and measure, to study pieces of history or botany (etc.), to take pictures and follow certain phenomena, to explore cities or the wild landscape and to develop a personal strategy and tactics or time management skills. Turned into play, the abovementioned aspects serve the interests of an attractive hobby, and, as a result, people can enjoy the experience of doing everyday businesses and play at the same time. Computing technology with its options and benefits helps to enrich both behavioural realms pulled into geocaching and create the feeling of engagement into an integral mode of being through it.

In reflecting on the essence of play, theorists and/or gamers have addressed the distinction between work and play as another contrast to deal with. In the 21st century play is not treated as something unproductive, done for fun, or pure waste by default, even more: in certain contexts it just doesn't make sense to regard work as serious and play as unserious (see Malaby 2007: 208). All the geocachingrelated tasks, except perhaps the seeking act itself, prove to be very work-like. As stated, more than creating a special realm out of everyday routines, play enables the augmentation and expansion of the experience gained by people involved. Of course, we cannot omit the similarity factor characteristic to play - in that sense, geocaching is like work, a simulation of data processing and their employment for the exploration of surroundings.

But does the hobby relate to the real job of participants and if yes, in what way? After all several, if not all, aspects of the game are represented in geocaching discussion forums and sometimes casually in cache listings, where the allocation of time to the hobby and the necessary tasks and activities is revealed. Discussing the issue, I can draw on the remarks of geocachers as well as on some community studies in which the relationship between play and work in hobbyists' time schedules was investigated. Although today the distinction between work and leisure is blurred (see, for example, Malaby 2009) and playfulness intrudes into occupational activities, we might assume that geocaching is a leisure time undertaking. Geocachers tend to have good skills in time management and can 


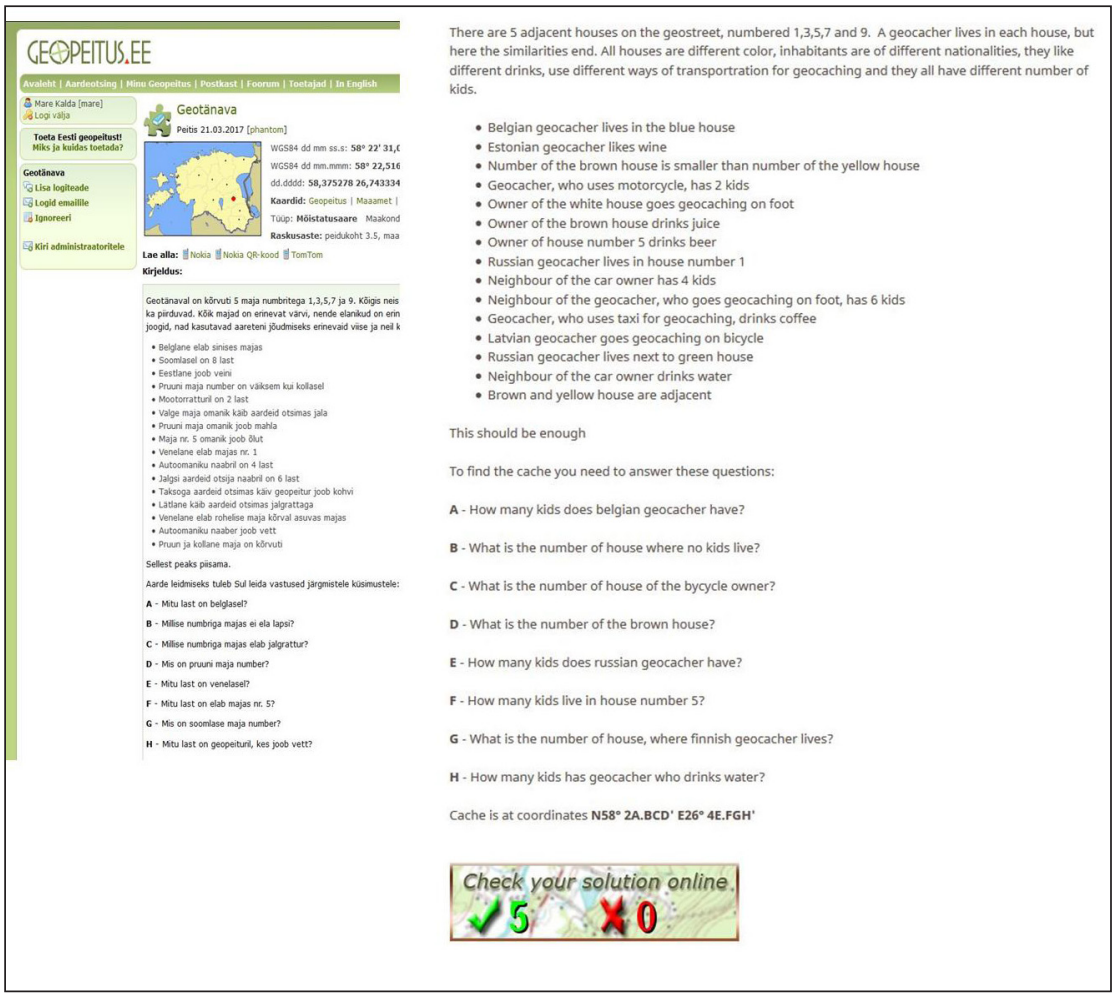

Figure 4. There are several types of geocaches in the game. An example of presentation of a puzzle cache information in the cache listing. A screenshot of the Geotänava cache on May 2, 2017.

exploit these abilities in order to excel both in work duties and in their hobby. ${ }^{\mathbf{5}}$ The timing of the geocaching activities of Germanspeaking geocachers was investigated by Daniel Telaar in his Diplomarbeit (Telaar 2007: 63-64, 80). Nearly 90\% of respondents preferred weekends for caching, but despite that, approximately $70 \%$ of interviewees confirmed sometimes having also participated in this activity on other days of the week (7.8\% never were). A proper geocacher, to a greater or lesser extent, pursues his/her hobby on 
vacation time and tends to spend free moments to locate nearby caches while on business trips (ibid.: 64). Of course, we have no data for how much time someone spends online communicating in discussion forums, preparing for the next find or every now and then keeping up with events. As a considerable number of gamers are engaged in information technology in a wider sense, they face opportunities (and temptations, see Hawley 2010: 235) to flexibly join their profession and geocaching.

However, in light of these factors, we have to consider the potential opposition between the ordinarity of work and the distinctiveness of geocaching, which would support the Huizinga's idea about apartness of play from everyday routines. This assertion is based on participants' reflections posted in discussion forums, for example, in a forum thread entitled "Why Do You Geocache?" (see http://forums.groundspeak.com/GC/index.php?showtopic=230444). A person under the username Lornix lists on January 28, 2010 his motives, among which we can find the opportunity "to forget the high-stress job if even for a couple of hours" - the assertion is supported later by a couple of other users and repeated in other contexts by other geocachers.

\section{A Kind of Secret Society?}

According to Huizinga, social groupings formed during the game will surround themselves with secrecy and begin to stress their difference from the rest of the world by certain means (Huizinga 2003 [1938]: 22). Since information necessary for playing is available on the public website(s), there might be no mystery around the hobby. Geocaching is everything but a secret society, which could accept invited and controlled members with special rituals. Nonetheless, the category of secrecy arises and is employed in hobbyists' self-reflection in order to explain what people are engaged in. Dana and Paul Gillin, being interested persons by themselves, refer to the words expressed in a forum by a user: "It's also kind of a secret society, operating under the noses of the general public" (Gillin \& Gillin 2010: 3). Computer scientist Risto Sarvas, one of the first analysts of geocaching, emphasises perception of a common secret - "treasures" are actually obtainable by almost everyone who wants to do so, yet those who know the secret belong to the 
community of geocachers (2002: 10 ; see also Neustaedter \& Tang \& Judge 2010: 1758). Thus, the knowing of what is actually going on distinguishes the playing community from the non-playing persons, called geomuggles in group terms (compare mugu in Estonian).

One thing is to keep the actions secret from passers-by. In the era of geocaching, people are used to working in crowded places without attracting undue attention. ${ }^{6}$ Strategies for how to be discreet during the search are repeatedly discussed in forum posts as well as cache logs, where some related stories illustrating the case are provided. Let's have a look, for example, at the cache hidden in the small town of Viljandi in Estonia. Twenty logs among more than 200 entries on the webpage of Üllatus ('Surprise') include hints to problems muggles met near the location of the geocache. The tiny square was often said to be too crowded for proper seeking and the geocaching teams had spent a lot of time just waiting for other people to leave. A geocacher under the username Silja wrote in July 2012:

A muggle living in the same street came to have a look at what people were doing under the same tree all the time. As it was raining, we could say we were seeking shelter from the rain, and showed the children where gnomes could hide in the summer. (see Üllatus)

Silja's story reveals that communication in casual interactions sometimes arise between geocachers and non-geocachers. The interaction with the non-playing audience does not necessarily mean lying or inventing quick explanations to conceal the real motives of an outing. It can happen that geocaching needs to be introduced to a local habitant, especially for non-urban caches, where under certain conditions honesty ought to be the best choice. As a result, the former muggle, perhaps without becoming an active geocacher himself or herself, could take the role of a voluntary guide for the next comer. This kind of geocaching tour "guided" by a local knower is described by Miki (see Sakala) who tells in his log how he and his fellow geocachers were wandering around without results until a local lady, tired of the dog's barking came and suggested that they find the sought-for box from under the stone. A special kind of interaction is revealed in the next example in which the activity couldn't have been kept secret. The geocacher Valap shares his 
experience gained by hiding his next geocache in Pärnu, Estonia, in November 2012:

While I was hiding a cache [---], I was caught in act by an unregistered user - the Estonian police. A vigilant citizen had informed them that a middle-aged man was trying to commit suicide on one of the bridges in Pärnu. My behaviour must have left such an impression on the bystander. However, due to the fact that the cache was rated 1.0 for terrain and 2.0 for difficulty, it would have been quite difficult or even impossible to inflict any self-harm-deliberate or otherwise - at the given location. Fortunately, the beautiful policewoman (I wonder since when do we have models working for the police force?) knew about geocaching as such. Moreover, once she had even participated in the search process of the cache of "Pärnu pier" (which I still have not found). I confessed honestly that I did not have any self-destructive plans. Quite the contrary. As I am especially interested in reading the logs about finding this particular cache, I would not do it in the near future either. After my documents had been checked, we departed as friends. The police refused to leave an FTF (First to Find) in the logbook. So, if you are seeking this cache, you can wave to the blue-and-white car passing by - these are friends. Well, this is how we live here in Pärnu. (see Teolt tabatud)

Though the request of not attracting undue attention is not explicitly formulated in the description of the hobby, geocachers follow it by default and such a warning is given in the rules of the local Estonian geopeitus. When the container has been placed in a crowded area, the cache owner adds a "muggle alert" to the cache's description for fellow seekers to keep in mind. Sometimes it is recommended to play the shoelace trick in which the geocacher stoops, pretending to tie their shoelace in order to get the cache out and put it back again - the method that works when it is necessary to crouch down to take something that has been placed low on the ground. Over the years this trick has become a formulaic concept in the practice of geocaching. Geocachers with kids employ another mode of pretence, since children supposedly help to cover the real intentions of what is actually going on. For example, the geocacher Karamellielli remarked in December, 2009: "Luckily I had enough children, 
trollers and other people with me, so we made a nice barricade near the cache and had no troubles with muggles at all. TFTC!" (see Old Thomas/Vana Toomas).

One reason to avoid too much publicity is simply to protect the game facilities from getting lost or plundered. Unfortunately, some containers get vandalised by destructively minded occasional finders. A cache from the start-up of the game included, among little toys and trinkets, some currency valid at that time. Money was taken and someone had scrawled into the logbook a very out-of-gamesounding request to put in more money next time. On the other hand, in certain cases casual finders will join or even play along: we can find supportive and interested entries in log books written by non-geocachers in the same way the true geocachers do.

A mystery also matters inside the game: to solve mysteries is really challenging for people involved. For an individual gamer, every particular geocache will remain an unsolved riddle until it is found, i.e. we can speak about kinds of secret tasks given to members of the community. Paradoxically, we are in on a secret anyone could uncover, and in spite of that, it still creates a feeling of mystery.

The attention by the community to the secrecy in deeds and words around the shared hobby indicates that the play feature under discussion really does work with regard to geocaching and influences the hobby group's identity. The data processing aspect of geocaching is mostly carried out in the digital environment and enables, in a sense, strategic planning to be developed. Yet the secret-keeping side of the game is a tactical skill: depending on the context, everyone can play their own way, choosing the right moment and actions for a real search.

\section{Players' Mindset and the Geocaching Mood}

A peculiar feature of play highlighted by Huizinga constitutes the players' mindset that, of course, relates to the factors discussed above. Even if we agree that the special play world is actually not set up for geocaching and play cannot be differentiated from ordinarity, participants confess to being in the geocaching mood. It's certainly something to perceive rather than express verbally, but like all aspects of the game revealed by players, a few hints 
are given. For example, the seekers of the hard-to-find Giprodornii cache in North Estonia report in January, 2014:

In a good geocaching mood, suitably dressed, decided to score and take the next cache. No problems with finding, however unexpected phobia occurred when near, so we were in a hurry to log the find. :) We did it this way: the biggest geocacher among us went up. Probably not the smartest choice, although the surroundings were scrubbed clean by the former finders and our geocaching clothing did not get dirty at all. Nice climbing, Thank you! TNLN! (see Giprodornii)

In a sense, the play mood is quite easy to get into due to the play drive we have naturally (see Frissen \& de Mul \& Raessens 2013: 78 and references), or because of our readiness to behave playfully in certain situations. The question is if the geocacher's state of mind resembles the state of mind which arises while playing any other game. Unlike other reflections about the game often commented about on the webpages of the hobby, this side of the phenomenon tends to remain somewhat hidden and will need additional inquiry. Of course, what has been said about games in general works for geocaching as well. The game designer and researcher Gonzalo Frasca holds that a particular state of mind is actually a factor to turn the otherwise non-play activity into a playful one (Frasca 2007: 51). Accordingly, actions performed by the participants for pursuing their hobby also generate a geocaching mood, the special feeling of engagement that inspires people to carry on with the play. The shared nature of the hobby also helps maintain the proper geocaching attitude: people want to act like others in the community. They feel obliged to share their experiences and thoughts connected to the common action, and at the same time wish to be familiar with the deeds and thoughts of fellow hobbyists. By hiding new caches and seeking old ones, participants can mutually create various opportunities for each other to obtain geocaching experiences and feelings that arouse emotions and in that way enhance their mood.

Let's have a look, for example, at the statement by [vaimar] related via the webpage of We will not meet on closed-off roads any morecache: 
I love geocaching because of caches like that, and because of location and story of the cache. If [irokas] will create your mood [i.e. irokas has prepared the cache hide], you have to be ready for a fanny adventure, or racking your brains or both. (see Suletud teedel ---)

Thus, the feeling of engagement and pleasure create the geocacher's mindset more generally. At the same time, participating in caching, people fall (and sometimes do not) into a heightened mood every time again. According to logs, not being in the be proper mood could result in Did Not Find. This happens when the seemingly out-ofgame circumstances (phone call coming from the non-geocaching world, tired participants, bad weather conditions, etc.) intrude into the hobby-related actions. But the truth is that people tend to relate almost all kinds of details and matters with the actions they are involved in, making them playful and/or rhetorically marking part of the game. In that sense, any weather will be good geocaching weather (even the rainiest), humans and creatures met during the search will function as treasure guardians from the perspective of the geocachers and experiences gained while hiding and seeking caches are considered geocaching experiences. Such interpretations work due to the geocaching mindset people have. Discussing the matter, I am not going to identify the mood with the mindset because you may not be in a geocaching mood but still have a geocaching mindset. Therefore, being in an inappropriate mood is not necessarily an explanation for Did Not Find. At the same time, a negative result could influence the way hobbyists view the particular situation. An unsuccessful search is also a part of the game and is acknowledged by players as a specific aspect of the geocaching experience.

The topic of the geocaching mindset actualises in-game reflection and influences the gaming behaviour, sometimes intruding into the non-geocaching lives of hobbyists. For example, people even recall having geocaching dreams. On the one hand, this phenomenon reflects very personal mental experiences regarded as relevant but not too intimate to be shared within gaming community. On the other hand, the stories geocachers tell about their dreams also have a place in hobby group folklore (see, for example, http://www. geocaching.com/blog/2015/03/5-geocaching-dreams-and-how-to- 
interpret-them/, or Estonian forum discussion including the funny list of features referring to geocaching addiction, http://www.geopeitus.ee/foorum/read.php?1,8028,page=1).

\section{In Conclusion}

The playground of geocaching extends all over the world, and the chosen sites are "marked" by special treasure boxes with their virtual representations in the virtual universe. In geocaching, the actions can be distinguished little or relatively little from ordinary life; game stages are dispersed between non-game activities, although they can be performed as serial missions. The framework of the game, which suggests an idea of activeness projecting from other activities, can still be deduced - it is marked by the preparation for the immediate search by way of a virtual platform (downloading of data, finding the coordinates for the location, solving riddles) and this is pointed out in the physical world by the actions carried out for the sake of geocaching. The participants realise that they are engaged consciously and voluntarily with something that they create and maintain with joint effort and they appreciate it. Perceiving and experiencing the environment happens individually and may be different for different people. There is also a high degree of freedom in how the situations and settings are recognised, named, interpreted and valued by those who become involved in them. According to Roger Abrahams, we may refer to the level of participation in events in our lives in terms of the relative presence of rituals, performances, games or festivities without classifying every case as a performance, a game or a festivity (Abrahams 1977: 108). Consequently, geocaching can be regarded as a kind of metagame, as within its framework several facets of the play manifest themselves - both performative and representational elements. At the same time, it incorporates the features of previously known traditional games, the motifs of cultural expressions and episodes from popular culture. Geocaching enables shared contributions and rivalry, provides peaceful entertainment, requires hard work to solve riddles and involves risk, or means just secure walking. Practicing the hobby, geocachers acquire physical and mental experiences by which they enrich their sense of being in the world. At the same time, geocaching and other games like it tend to blur 


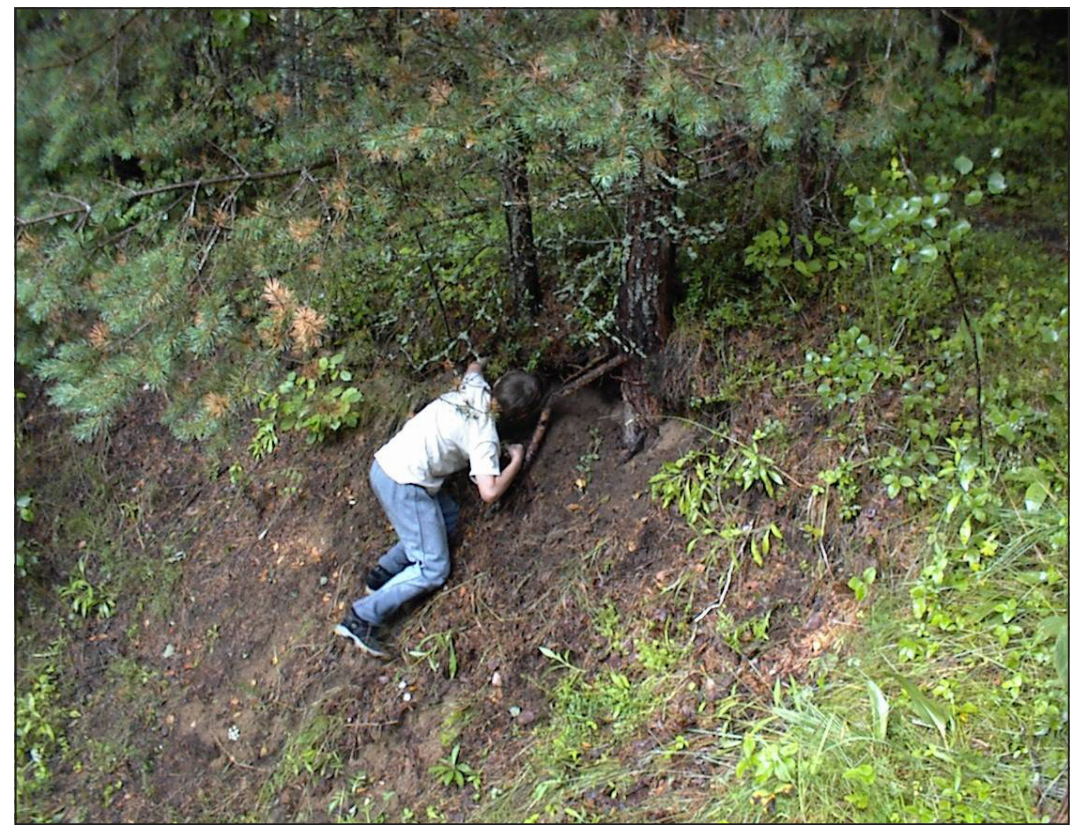

Figure 5. The final steps of the cache search (the MASS cache in Läänemaa, Estonia, archived for now). Photo by Ain Kalda (2004).

the definitions of play and gaming, and change the ways in which human activities are categorised and understood. Named processes influence the thoughts people think and the deeds they do.

\section{Notes}

${ }^{1}$ The webpage geocaching.com run by Groundspeak, Inc., functions as an online information centre for the whole geocacher community. It provides the history of geocaching, explains the rules and instructions of the game and contains cache listings where hobbyists log their visits and share the game-related experiences. Forums structured by various topics, in which participants actively discuss the game and even tell stories, can be found at http://forums.groundspeak.com/GC/. 
${ }^{2}$ For example, the media theorists and game researchers Joos Raessens and Valerie Frissen together with philosopher Jos de Mul emphasise the difference between old and new phenomena by "playing" with the concept Homo ludens 1.0, considering playfulness in a historical perspective versus Homo ludens 2.0, which describes the playful dimension of information and communication technologies (Frissen \& de Mul \& Raessens 2013: 75-76).

${ }^{3}$ To be correct, his characterisation of Bliin should be read partly conversely in order to fit geocaching's description: if by Bliin "the digital space is augmented by movements in the physical world, and real world information and experiences are ... made accessible via the web interface ... running on the mobile phone" (de Lange 2009: 61), in geocaching the physical world is augmented by actions performed in the digital space.

${ }^{4}$ The passage has been repeatedly quoted and elaborated in game studies. Katie Salen and Eric Zimmermann (2004) conditionally expanded the notion of the magic circle to embrace all playgrounds. This induced a plethora of imprecise references, as if Huizinga had claimed that play happens in a magic circle strictly separated from the ordinary world. Montola, Stenros and Waern (2009: 7-8) as well as Cristopher Moore (2011: 373, 377) point out that Huizinga's book has been read superficially or even misinterpreted.

${ }^{5}$ Francis Hawley still openly assumes from the content of caching logs and the frequency of finds during weekdays, how "many of cachers use work time, equipment, and vehicles, for the furtherance of their pastime" (Hawley 2010: 235).

${ }^{6}$ Several inventive examples from geocaching around the world are provided by Gillin \& Gillin (see 2010: 86-87).

\section{Acknowledgement}

The article was supported by institutional research grant IUT22-5 from the Estonian Ministry of Education and Research and by the European Union through the European Regional Development Fund (Centre of Excellence in Estonian Studies).

\section{References}

Abrahams, Roger 1977. Toward an Enactment-Centered Theory of Folklore. William Bascom (ed.). Frontiers of Folklore. Boulder: Westview Press, pp. 79-120. 
Aarseth, Espen 2003. Playing research: Methodological approaches to game analysis. Paper presented at the 5th Digital Arts \& Culture Conference, Melbourne, Australia.

http://www.cs.uu.nl/docs/vakken/vw/literature/02.GameApproaches2.pdf (Accessed on May 27, 2013).

Anderson, Leon 2006. Analytic Autoethnography. Journal of Contemporary Ethnography, 35 (4), pp. 373-395, http://dx.doi.org/10.1177/0891241605280449.

Blank, Trevor 2009. Toward a Conceptual Framework for the Study of Folklore and the Internet. Folklore and the Internet: Vernacular Expression in a Digital World. USU Press Publications, 35. Logan: Utah University Press, pp. 1-20.

Boellstorff, Tom 2008. Coming of Age in Second Life. An Anthropologist Explores the Virtually Human. Princeton \& Oxford: Princeton University Press.

De Lange, Michiel 2009. From always on to always there: Locative media as Playful Technologies. A. de Souza e Silva and D. M. Sutko (eds.). Digital cityscapes: merging digital and urban playspaces. New York: Peter Lang, pp. 55-70.

Farman, Jason 2009. Locative Life: Geocaching, Mobile Gaming, and Embodiment. Proceedings of the Digital Arts and Culture Conference, University of California, Irvine 2009 [Online].

http://www.escholarship.org/uc/item/507938rr (Accessed on Apr 5, 2010).

Frasca, Gonzalo 2007. Play the Message. Play, Game and Videogame Rhetoric. Ph.D. Dissertation. Copenhagen: IT University of Copenhagen. http://www.powerfulrobot.com/Frasca_Play_the_Message_PhD.pdf (Accessed on June 14, 2015).

Frissen, Valerie \& de Mul, Jos \& Raessens, Joost 2013. Homo ludens 2.0: Play, Media and Identity. Judith Thissen, Robert Zwijnenberg and Kitty Zijlmans (eds.). Contemporary Culture. New Directions in Art and Humanities Research. Amsterdam: Amsterdam University Press, pp. 75-92. http://www.demul.nl/nl/publicaties/publicaties-per-categorie/boekbijdragen/item/1635-homo-ludens-2-0-play,-media-and-identity

Georges, Robert 1972. Recreations and Games. Folklore and Folklife: An Introduction. Chicago: The University of Chicago Press, pp. 173-190. 
Gillin, Dana \& Gillin, Paul 2010. The Joy of Geocaching: How to Find Health, Happiness and Creative Energy Through a Worldwide Treasure Hunt. Linden Publishing.

Gram-Hansen, Lasse 2009. Geocaching in a Persuasive Perspective. Persuasive'09. Proceedings of the 4th International Conference on Persuasive Technology, April 26-29, Claremont, California. ACM International Conference Proceeding Series, 350, pp. 1-8.

http://dx.doi.org/10.1145/1541948.1541993

Harambam, Jaron \& Aupers, Stef \& Houtman, Dick 2011. Game over? Negotiating modern capitalism in virtual game worlds. European Journal of Cultural Studies, 14 (3), pp. 299-319.

Hawley, Francis Frederik 2010. Agon and Ecstasy: Transgression, Transformation, and Transcendence in Competitive Geocaching. Deviant Behavior, 31 (3), pp. 225-250.

http://dx.doi.org/10.1080/01639620902855024.

Huizinga, Johan 2003 [1938]. Mängiv inimene. Kultuuri mänguelemendi määratlemise katse [Homo Ludens: A Study of the Play-Element in Culture]. Tallinn: Varrak.

Ihamäki, Pirita Johanna 2012. Geocaching: Interactive Communication Channels Around the Game. Eludamos. Journal for Computer Game Culture, 6 (1), pp. 133-152.

Jennings, Ken 2011. Maphead: charting the wide, weird world of geography wonks. New York: Scribner Book Company.

Juul, Jesper 2009. Casual revolution: Reinventing Video Games and Their Players. Cambridge: MIT Press.

Kalda, Mare 2007. Muistendid uues kontekstis - geopeituses [Integration of Legends into Geocaching]. Mare Kõiva (comp.). Paar sammukest XXIII. Eesti Kirjandusmuuseumi aastaraamat. Tartu: Eesti Kirjandusmuuseumi teaduskirjastus, pp. 93-116.

http://www.folklore.ee/rl/pubte/ee/araamat/2007/4marekalda.pdf (Accessed on May 27, 2013).

Kalmre, Eda 2005. Laste- ja noortepärimus [Children and Youth Lore]. Merili Metsvahi \& Ülo Valk (comps.). Regivärsist netinaljadeni. Sissejuhatus rahvaluulesse. Tallinn: Koolibri, pp. 163-179.

Krikmann, Arvo 2005. Naljandid ja anekdoodid [Anecdotes and Jokes]. Merili Metsavahi \& Ülo Valk (comps.). Regivärsist netinaljadeni: Sissejuhatus rahvaluulesse. Tallinn: Koolibri, pp. 63-77. 
Lotman, Juri 2011 [1967]. The place of art among other modelling systems. Sign Systems Studies, 39 (2-4), pp. 249-270.

Malaby, Thomas 2007. Beyond Play. A New Approach to Games. Games and Culture, 2 (2), pp. 95-113.

http://dx.doi.org/10.1177/1555412007299434.

McNeill, Lynne 2007. Portable Places: Serial Collaboration and the Creation of a New Sense of Place. Western Folklore, 66 (3/4), pp. 281-300.

Montola, Markus \& Stenros, Jaakko \& Waern, Annika 2009. Pervasive Games: Theory and Design. Amsterdam: Morgan Kaufmann.

Moore, Christopher 2011. The Magic Circle and the Mobility of Play. Convergence: The International Journal of Research into New Media Technologies, 17 (4), pp. 373-387.

http://dx.doi.org/10.1177/1354856511414350.

Neustaedter, Carman \& Tang, Anthony \& Judge, Tejinder 2010. The Role of Community and Groupware in Geocache Creation and Maintenance. Proceedings of the SIGCHI Conference on Human Factors in Computing Systems, 10-15 April 2010, Atlanta, Georgia. New York, pp. 1757-1766. http://hcitang.org/papers/2010-chi2010-geocaching.pdf http://dx.doi.org/10.1145/1753326.1753590

O'Hara, Kenton 2008. Understanding Geocaching Practices and Motivations. Proceedings of the 26th Annual SIGCHI Conference on Human Factors in Computing Systems, April 5-10, 2008, Florence, Italy, pp. 1177-1186. http://dx.doi.org/10.1145/1357054.1357239

Salen, Katie \& Zimmerman, Eric 2004. Rules of Play. Game Design Fundamentals. London: MIT Press.

Sarpong, David \& White, Gareth \& Skinner, Heather 2012. Harnessing the Technology Wave for Tourism: drawing on the community of practice of Human Search Engines. Paper presented at the Academy of Marketing Conference, July 2012: 'Marketing: Catch the Technology Wave'. University of Southampton's School of Management, [1-6].

http://marketing.conference-services.net/resources/327/2958/pdf/ AM2012_0129_paper.pdf (Accessed on May 27, 2013).

Stenros, Jaakko \& Waern Annika \& Montola, Markus 2012. Studying the Elusive Experience in Pervasive Games. Simulation \& Gaming, 43 (3), pp. 339-355.

http://dx.doi.org/10.1177/1046878111422532 
Zeng, Minhao 2011. Examining Geocaching Practices through a Mobility Lens. Twelfth Annual Convention, University of Alberta, Edmonton, Alberta, Canada, June 23-26, 2011. Proceedings of the Media Ecology Association, 12, pp. 113-122.

http://media-ecology.org/publications/MEA_proceedings/v12/3_examining. pdf

Telaar, Daniel 2007. Geocaching: Eine kontextuelle Untersuchung der deutschsprahigen Geocaching-Community. Diplomarbeit im Studiengang Geographie, Münster: Westfälische Wilhelms-Universität Münster, Institut für Geographie.

http://www.geocache.ch/daten/DA-Geocaching-2007-Telaar.pdf (Accessed on May 27, 2013).

Veenpere, Enn 2002. Aasta geopeitust Eestis [A Year of Geocaching in Estonia]. Arvutimaailm, 1, pp. 41-43.

http://vana.geopeitus.ee/lisad/geopeitus.html (Accessed on May 27, 2013).

\section{References to the webpages of geocaches and discussion forums introduced above (year denotes the year of hiding)}

Aastapäeva 2002. http://www.geopeitus.ee/aare/44 (Accessed on May 27, 2016.)

Batjuška 4 2010. https://www.geocaching.com/geocache/GC2EAEV_batjuska-4 (Accessed on May 2, 2017).

Geotänava 2017. http://www.geopeitus.ee/aare/4332 from geopeitus.ee (Accessed on May 2, 2017).

Giprodornii 2013. http://www.geopeitus.ee/aare/2608 (Accessed on July 14, 2016).

HE-aare 2001. http://www.geopeitus.ee/aare/1 (Accessed on May 27, 2013).

Is Geocaching A ... sport? 2005. http://forums.groundspeak.com/GC/index. php? showtopic $=97773 \&$ st $=0 \& p=1473997 \&$ fromsearch $=1 \& \#$ entry 1473997 (Accessed on May 27, 2013).

MASS 2004. http://www.geopeitus.ee/aare/228 (Accessed on May 2, 2017). 
"RASH" = The official "Geocaching Activity" acronym is now "RASH" 2002. http://forums.groundspeak.com/GC/inex.php?showtopic=56489 (Accessed on May 27, 2013).

Sakala 2003. http://www.geopeitus.ee/aare/129 (Accessed on July 13, 2016).

Suletud teedel... 2013. http://www.geopeitus.ee/aare/2729 (Accessed on May 27, 2016).

Teolt tabatud 2005. http://www.geopeitus.ee/aare/329 (Accessed on May 27, 2016).

Vandi 2009. http://www.geopeitus.ee/aare/1131 (Accessed on May 27, 2016).

Vana Toomas 2009. http://www.geopeitus.ee/aare/1194 and http://www. geocaching.com/geocache/GC1YN9H_old-thomas-vana-toomas (Accessed on March 16, 2016).

Üllatus 2005. http://www.geopeitus.ee/aare/342 (Accessed on May 27, 2016). 


\section{ELM Scholarly Press \\ SATOR 18}

http://dx.doi.org/10.7592/Sator.2017.18

\section{BALKAN AND BALTiCUM}

Current Studies in the Postsocialist Space

Edited by

Ekaterina Anastasova and Mare Kõiva

Tartu 2017 
Editors and compilers: Ekaterina Anastasova, Mare Kõiva Series "Sator" editor: Mare Kõiva

Language editors: Liisa Vesik, Lii Liin

Cover photo: Jaak Kikas, 2017 "Autumn in Tartu"

International committee

Tiiu Jaago (Tartu University); Reet Hiiemäe (Estonian Literary Museum); Mare Kalda (Estonian Literary Museum); Tarmo Kulmar (Tartu University); Nikolay Kuznetsov (Estonian Literary Museum); Aado Lintrop (Estonian Literary Museum); Emily Lyle (School of Scottish Studies in Edinburgh); Mirjam Mencej (Ljubljana University); Jonathan Roper (Tartu University); Marju Kõivupuu (Tallinn University); Ülo Valk (Tartu University); Tatjana Vladõkina (Institute of Udmurtian History, Language and Literarture, Izhkar); Irina Vinokurova (Institute of Karelian History, Language and Literarture in Petroskoi); Ergo-Hart Västrik (Tartu University)

Supported by Estonian Academy of Sciences, Bulgarian Academy of Sciences, the Centre of Excellence in Estonian Studies (CEES, European Regional Development Fund) and is related to research projects IRG 22-5 (Estonian Research Council).

\section{$\boldsymbol{C} E \mathbf{E} \times \begin{aligned} & \text { Centre of excellence } \\ & \text { in Estonian Studies }\end{aligned}$}

Series "Sator. Artikleid usundi- ja kombeloost", 18 http://www.folklore.ee/rl/pubte/ee/sator/sator18/

ISSN 1736-0323 (online)

ISBN 978-9949-586-58-5 (printed)

ISBN 978-9949-586-61-5 (online) ISSN 1406-2011 (printed)

DOI: 10.7592/Sator.2017.18

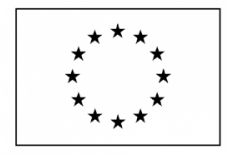

European Union European Regional Development Fund

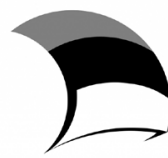

Investing in your future

\section{EUROPEAN UNION}

Regional Development Fund

Investing in your future
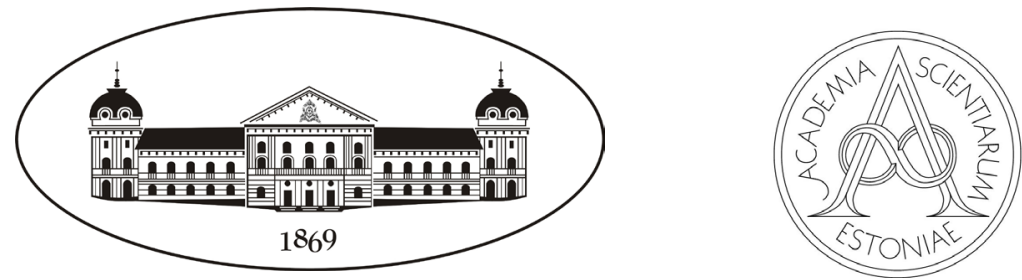


\section{Contents}

Preface

Mare Kõiva, Ekaterina Anastasova

CONSTRUCTING IDENTITY AND SOCIAL TIES

Ethnographic Studies on the Montenegrin

Festive Costume as a National Symbol

Sofiya Zahova

Social Ties of Bulgarians and Rudari in the Mediterranean Countries

Magdalena Slavkova

\section{RECASTING RELIGION AND \\ RELIGIOUS IDENTITY}

Contemporary Development of the Akyazili

Baba Tekke / St. Athanasius in Bulgaria

Yelis Erolova

Turkish Religious Identity in Bulgaria

94

in the Last Twenty-Four Years (1989-2013)

Mila Maeva

The Feast of Cyril and Methodius in Bessarabia and Crimea, Ukraine

Ekaterina Anastasova 
The Saints of Death in the Traditions

of the Balkan People

Rachko Popov

\section{CONSTRUCTING NEW SPIRITUALITY}

New Trends in the Study of Religion in Estonia -

Contemplations in the Grey Zone between

Religion and Science

Tõnno Jonuks

Constructing New Spirituality in Modernity -

the Case of the White Brotherhood in Bulgaria

Svetoslava Toncheva

Constructing Contemporary Periodical and

Occasional Rituals

Mare Kõiva

The Making of a Sacred Place:

221

An Example of Constructing Place Identity in the Contemporary Mentality

Reet Hiiemäe

\section{CHANGING TRADITIONS}

Bridge Over the Rainbow. Animal Burials and

Animal Cemeteries in Post-Socialist Estonia

Marju Kõivupuu

Simple Hide-and-seek at its Core: Play Features and the Game of Geocaching

Mare Kalda 